\title{
Clostridium lavalense sp. nov., a glycopeptide- resistant species isolated from human faeces
}

\author{
M.-C. Domingo, ${ }^{1,2}$ A. Huletsky, ${ }^{1,2}$ M. Boissinot, ${ }^{1,2}$ M.-C. Hélie, ${ }^{1}$ A. Bernal, ${ }^{1}$ \\ K. A. Bernard, ${ }^{3,4}$ M. L. Grayson, ${ }^{5}$ F. J. Picard ${ }^{1,2}$ and M. G. Bergeron ${ }^{1,2}$
}

\begin{abstract}
Correspondence
Michel. G. Bergeron michel.g.bergeron@crchul. ulaval.ca
\end{abstract}

\author{
${ }^{1}$ Centre de Recherche en Infectiologie de l'Université Laval, CHUQ, Pavillon CHUL, 2705 boulevard \\ Laurier, Québec, Québec, Canada G1V 4G2 \\ ${ }^{2}$ Division de Microbiologie, Faculté de Médecine, Université Laval, Québec, Canada \\ ${ }^{3}$ National Microbiology Laboratory, Health Canada, H5040-1015 Arlington Street, Winnipeg, \\ Manitoba, Canada \\ ${ }^{4}$ Department of Medical Microbiology, University of Manitoba, Winnipeg, Canada \\ ${ }^{5}$ Infectious Diseases Department, Austin Health, Melbourne, Australia
}

Accurate analysis of the microbial ecosystem in the human digestive tract is always a challenging topic for microbiologists because of the interactions between complex bacterial communities and host cells and also because of the implications for human health (Backhed et al., 2005; Hooper et al., 2002; Zoetendal et al., 2006). The microbiota of the human gut has been investigated extensively, using both traditional culture methods and molecular techniques, and has been found to contain a large number of unknown species belonging to the 19 phylogenetic clusters of the genus Clostridium (Collins et al., 1994; Eckburg et al.,

\section{Abbreviation: MIC, minimum inhibitory concentration.}

The GenBank/EMBL/DDBJ accession numbers for the $16 \mathrm{~S}$ rRNA gene sequences of strain CCRI-9842 ${ }^{\top}$ and CCRI-9929 are EF564277 and EF564278, respectively.

Neighbour-joining, maximum-parsimony and maximum-likelihood cladograms, based on $16 \mathrm{~S}$ rRNA gene sequences of strains CCRI- $9842^{\top}$ and CCRI-9929 and related taxa, are available as supplementary figures with the online version of this paper.
2005; Suau et al., 1999). The bacteria most frequently detected in human faeces can be classified as belonging to three major groups. One group comprises the low $-\mathrm{G}+\mathrm{C}$, Gram-positive organisms (46-58\%), as follows: the Clostridium coccoides-Eubacterium rectale group (also known as cluster XIVa) (22.7-28\%), the Clostridium leptum group (also known as cluster IV) (21.1-25.2\%), the LactobacillusEnterococcus group $(<0.1-1.8 \%)$, the Eubacterium cylindroides group $(1.1-1.4 \%)$, the Veillonella group $(<0.1-$ $1.3 \%)$ and the Phascolarctobacterium group $(0.6 \%)$. The next category consists of Gram-negative organisms (10$30 \%)$ : the Bacteroides-Prevotella group (8.5-28\%), the family Enterobacteriaceae (0.1-0.2\%) and the genus Akkermansia $(1.3 \%)$. Finally, there are the high- $\mathrm{G}+\mathrm{C}$, Grampositive organisms $(8-17 \%)$ represented by the genera Atopobium (3.1-11.9\%) and Bifidobacterium (4.4-4.8\%) (Zoetendal et al., 2006).

Two strains, CCRI-9929 (=NML 03-A-014=MLG245) and CCRI-9842 ${ }^{\mathrm{T}} \quad\left(=\mathrm{NML} 03-\mathrm{A}-015^{\mathrm{T}}\right)$ were isolated during 
screening of human faecal specimens to detect carriers of vancomycin-resistant enterococci (Ballard et al., 2005; Domingo et al., 2005; Stinear et al., 2001). In this study, we characterized the phenotypic profiles and phylogenetic relationships of these two strains. The data from this polyphasic taxonomic analysis, presented here, revealed that these strains represent a novel species of the genus Clostridium.

During a screening programme for the detection of vancomycin-resistant enterococci in clinical settings in Québec (Canada) and Melbourne (Australia), two anaerobic bacterial strains, CCRI-9929 and CCRI- $9842^{\mathrm{T}}$, were isolated, respectively, from faecal specimens of patients tested for colonization by vancomycin-resistant enterococci (Ballard et al., 2005; Domingo et al., 2005; Stinear et al., 2001). No further information was collected from these patients. The isolates were stored at $-80{ }^{\circ} \mathrm{C}$ in brain heart infusion (BHI; Difco) $+20 \%$ glycerol media until the identification tests could be performed. These strains were subcultured twice on BHI blood agar containing haemin $\left(0.005 \mathrm{mg} \mathrm{ml}^{-1}\right)$ and vitamin $\mathrm{K}\left(0.001 \mathrm{mg} \mathrm{ml}^{-1}\right)$. Phenotypic identification tests were performed as described in the Wadsworth and VPI anaerobic manuals (Holdeman et al., 1977; Jousimies-Somer et al., 2002) at the Centre de Recherche en Infectiologie, Université Laval, Québec, Canada, and at the National Microbiology Laboratory, Winnipeg, Canada. Morphology was observed using light microscopy (Leitz) and transmission electron microscopy (1200EX; JEOL). Growth was observed in peptone-yeast broth enriched with glucose, with or without bile, serum, Tween 80 or formate-fumarate (Jousimies-Somer et al., 2002). Special-potency discs (Oxoid) containing colistin $(10 \mu \mathrm{g})$, kanamycin $(1000 \mu \mathrm{g})$, vancomycin $(5 \mu \mathrm{g})$ and metronidazole $(5 \mu \mathrm{g})$ were used to group the anaerobic bacteria, as recommended in the Wadsworth manual (Jousimies-Somer et al., 2002). Minimum inhibitory concentrations (MICs) for vancomycin and metronidazole were determined using the agar dilution method for anaerobes according to the Clinical and Laboratory Standard Institute (NCCLS, 2004). The MIC for teicoplanin was determined using the Etest method ( $\mathrm{AB}$ Biodisk). Fermentation tests were performed for various sugars using prereduced, anaerobically sterilized peptone-yeast sugar broth tubes (Med-Ox Diagnostics). Other tests, such as those for catalase, aesculin, indole, lecithinase, lipase, nitrate and oxidase, were performed as described previously (Jousimies-Somer et al., 2002). The novel isolates were examined (according to the manufacturers' instructions) using enzyme test kits including the Rapid ID 32A and API ZYM systems (bioMérieux) and the Rapid ANA II system (Remel). GLC analysis of the metabolic end products of fermentation was performed as described previously (Bernard et al., 2002) except that anaerobe system broth was acquired from Med-Ox Diagnostics. Cellular fatty acid composition and library generation analyses were performed using the MIDI Sherlock system and LGS software (MIDI), as described previously (Bernard et al., 2002).

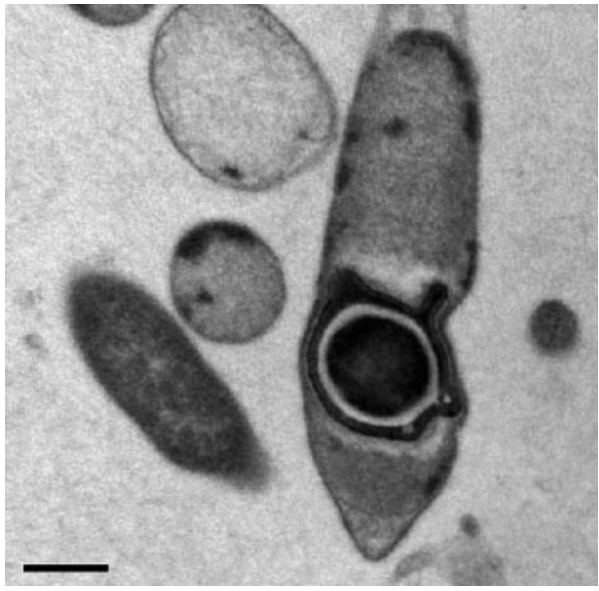

Fig. 1. Transmission electron micrograph of thin-sectioned cells of strain CCRI-9842 ${ }^{\top}$. Bar, $0.5 \mu \mathrm{m}$.

Strains CCRI-9842 ${ }^{\mathrm{T}}$ and CCRI-9929 comprised strictly anaerobic, Gram-positive, rod-shaped cells $(0.8-1.5 \mu \mathrm{m}$ wide by $2.5-6.0 \mu \mathrm{m}$ long) with tapered ends. Subterminal spores were observed (Fig. 1). The isolates grew well anaerobically, but no growth occurred following subculture under $5 \% \mathrm{O}_{2}$. Growth was enhanced in the presence of glucose and formate-fumarate for both strains, and in the presence of bile and serum in the case of strain CCRI-9929 (Table 1). Neither strain was inhibited by Tween 80 . After $48 \mathrm{~h}$ incubation on blood agar at $37{ }^{\circ} \mathrm{C}$ under anaerobic conditions, colonies of both strains were $2-3 \mathrm{~mm}$ in diameter, greyish white in colour and had irregular edges. The centres of the colonies were slightly raised and no zones of haemolysis were observed on blood agar. Colonies of strain CCRI-9842 ${ }^{\mathrm{T}}$ were strongly adherent on blood agar whereas those of strain CCRI-9929 were non-adherent on the same medium. This adherence of strain CCRI- $9842^{\mathrm{T}}$ declined progressively after several subcultures on agar medium. Cells of both novel isolates were motile. The isolates were indole-positive and catalase-negative. Nitrate was reduced by strain CCRI- $9842^{\mathrm{T}}$ but not by strain CCRI9929. No liquefaction of gelatin or peptonization of milk occurred in either strain. Neither strain hydrolysed urea or starch. Analysis using special potency discs showed that both strains were susceptible to $1000 \mu \mathrm{g}$ kanamycin and $5 \mu \mathrm{g}$ metronidazole and that both were resistant to $10 \mu \mathrm{g}$ colistin and $5 \mu \mathrm{g}$ vancomycin. MIC determinations showed that both strains were resistant to vancomycin (MIC> $256 \mu \mathrm{g} \mathrm{ml}^{-1}$ ) but were susceptible to teicoplanin (MIC $<$ $1.5 \mu \mathrm{g} \mathrm{ml}^{-1}$ ) and metronidazole $\left(\mathrm{MIC}<0.064 \mu \mathrm{g} \mathrm{ml}^{-1}\right.$ ). The enzyme profile obtained using Rapid ID 32A and API ZYM tests is summarized in Table 1. Both strains belong to the genus Clostridium, being obligatory anaerobic, endospore-forming, Gram-positive bacilli. On the basis of their cultural and biochemical characteristics, as well their glycopeptide susceptibility profile, it was evident that these 
Table 1. Characteristics useful for differentiating strain CCRI$9842^{\top}$ from the type strains of closely related members of the genus Clostridium

Strains: 1, CCRI-9842 ${ }^{\mathrm{T}}$; 2, Clostridium asparagiforme DSM $15981^{\mathrm{T}}$ (data from Mohan et al., 2006); 3, Clostridium bolteae WAL $16351^{\mathrm{T}}$ (Song et al., 2003); 4, Clostridium clostridioforme ATCC $25537^{\mathrm{T}}$ (Mohan et al., 2006). +, Positive; -, negative; w, weak reaction; NA, data not available.

\begin{tabular}{|c|c|c|c|c|}
\hline Characteristic & 1 & 2 & 3 & 4 \\
\hline Indole production & + & + & - & - \\
\hline \multicolumn{5}{|l|}{ Acid from: } \\
\hline D-Arabinose & $\mathrm{W}$ & - & + & + \\
\hline Cellobiose & - & NA & NA & $\mathrm{NA}$ \\
\hline D-Mannose & + & - & + & + \\
\hline Raffinose & - & - & $\mathrm{NA}$ & + \\
\hline D-Ribose & $\mathrm{w}$ & NA & - & + \\
\hline D-Sorbitol & $\mathrm{w}$ & NA & + & - \\
\hline L-Xylose & $\mathrm{w}$ & - & + & + \\
\hline \multicolumn{5}{|l|}{ Enzyme activity } \\
\hline$\alpha$-Galactosidase & - & + & NA & $\mathrm{NA}$ \\
\hline$\beta$-Galactosidase & + & + & + & - \\
\hline$\alpha$-Glucosidase & - & + & - & + \\
\hline$\alpha$-Fucosidase & - & + & NA & $\mathrm{NA}$ \\
\hline $\begin{array}{l}\text { Naphthol-AS-BI- } \\
\text { phosphohydrolase }\end{array}$ & + & - & NA & NA \\
\hline$\beta$-Glucuronidase & - & - & $\mathrm{NA}$ & NA \\
\hline $\begin{array}{l}\text { End products of glucose } \\
\text { metabolism }^{*}\end{array}$ & $\mathrm{~A}, \mathrm{l}, \mathrm{s}$ & $\mathrm{A}, \mathrm{L}, \mathrm{f}, \mathrm{h}$, & A, L & A, L, E \\
\hline
\end{tabular}

${ }^{\star} \mathrm{A}$, acetic acid; E, ethanol; $\mathrm{f}$, formate; $\mathrm{h}$, hydrogen; $\mathrm{L}$ or $\mathrm{l}$, lactate; $\mathrm{s}$ succinic acid. Minor end products are indicated by lower-case letters.

isolates closely resembled each other and probably belonged to the same species.

Total DNA from strains CCRI-9842 ${ }^{\mathrm{T}}$ and CCRI-9929 was purified using the GNOME DNA kit (Qbiogene). Purified genomic DNA was used in PCRs to amplify a $1466 \mathrm{bp}$ region of the $16 \mathrm{~S}$ rRNA genes as described previously (Paradis et al., 2005). Sequencing of the specific amplification products was also performed as described previously (Domingo et al., 2005). To identify the taxonomic neighbours of strains CCRI-9842 ${ }^{\mathrm{T}}$ and CCRI-9929, 16S rRNA gene sequences were used for an initial BLAST search against the GenBank database. Subsequently, bacterial species closely related to both strains were used for a phylogenetic analysis. Multiple sequence alignments were performed using CLUSTAL $\mathrm{W}$ from the GCG package (Wisconsin Package, version 10.3; Accelrys). The phylogenetic analysis was carried out using the neighbourjoining (Saitou and Nei, 1987) and maximum-parsimony (Fitch, 1971) methods with MEGA, version 4 (Tamura et al., 2007). Evolutionary distance matrices were generated according to the Kimura two-parameter model (Kimura, 1980). Bootstrap values (\%) were calculated from 1000 resamplings. The final phylogenetic tree based on $16 \mathrm{~S}$ rRNA gene sequences was rooted with type strains of Fusobacterium nucleatum and Propionigenium modestum (cluster XIX) as the outgroup. The comparative 16S rRNA gene sequence analysis showed that isolates CCRI- $9842^{\mathrm{T}}$ and CCRI-9929 were genetically very closely related to each other, displaying $99.2 \%$ sequence similarity. Searches in the sequence database revealed that the novel isolates were closely related to members of cluster XIVa of the genus Clostridium (Collins et al., 1994). On the basis of $16 \mathrm{~S}$ rRNA gene sequence similarity, the closest relatives of the unidentified isolates were type strains of Clostridium asparagiforme (97\%), Clostridium bolteae (96\%) and Clostridium clostridioforme (95\%). A phylogenetic tree generated using a larger number of 16S rRNA gene sequences and constructed using the neighbour-joining and maximum-parsimony methods showed that the unknown anaerobic isolates fitted into the Clostridium coccoides rRNA complex (cluster XIVa of the genus Clostridium) (Collins et al., 1994) (Fig. 2 and Supplementary Figs S1 and S2, available with IJSEM Online). Cluster XIVa contains various genera, including Clostridium, Ruminococcus, Eubacterium, Acetitomaculum, Roseburia and Coprococcus (Collins et al., 1994). To elucidate the phylogenetic relationships between the novel isolates and the Clostridium species belonging to cluster XIVa, phylogenetic trees based on 16S rRNA gene sequences were constructed by using three different tree-making algorithms. The neighbour-joining (Fig. 2), maximum-parsimony (see Supplementary Fig. S3, available with IJSEM Online) and maximum-likelihood (Supplementary Fig. S4 in IJSEM Online) trees clearly demonstrated that the two novel isolates represent a hitherto unknown subline within cluster XIVa of the genus Clostridium. The isolates clustered within a distinct subgroup that included Clostridium asparagiforme, Clostridium bolteae, Clostridium clostridioforme, Clostridium citroniae and Clostridium aldenense. It is generally accepted that organisms displaying $16 \mathrm{~S}$ rRNA gene sequence dissimilarities close to $3 \%$ or more do not belong to the same species (Stackebrandt \& Goebel, 1994; Stackebrandt \& Ebers, 2006). Several characteristics, including morphology, biochemical profiles and the 16S rRNA gene sequence tree topology, were used to distinguish strains CCRI-9842 ${ }^{\mathrm{T}}$ and CCRI-9929 from the closely related species Clostridium asparagiforme. Strains CCRI- $9842^{\mathrm{T}}$ and CCRI-9929 were resistant to vancomycin and harboured the van $B$ gene cluster. The cellular morphology of these strains was different from the asparagus-shaped morphology of cells of Clostridium asparagiforme (Fig. 1). These novel isolates also differed from Clostridium asparagiforme in that they produced acid from arabinose, mannose and xylose (Table 1). Enzymic activities for the novel isolates differed from those of Clostridium asparagiforme DSM $15981^{\mathrm{T}}$ : the novel isolates showed negative reactions for $\alpha$-glucosidase, $\alpha$-fucosidase, $\alpha$-galactosidase and $\beta$-glucuronidase. For both novel isolates, acetic acid was the major end product, with minor yields of lactate and succinate from glucose metabolism; in contrast, acetic acid, lactate 


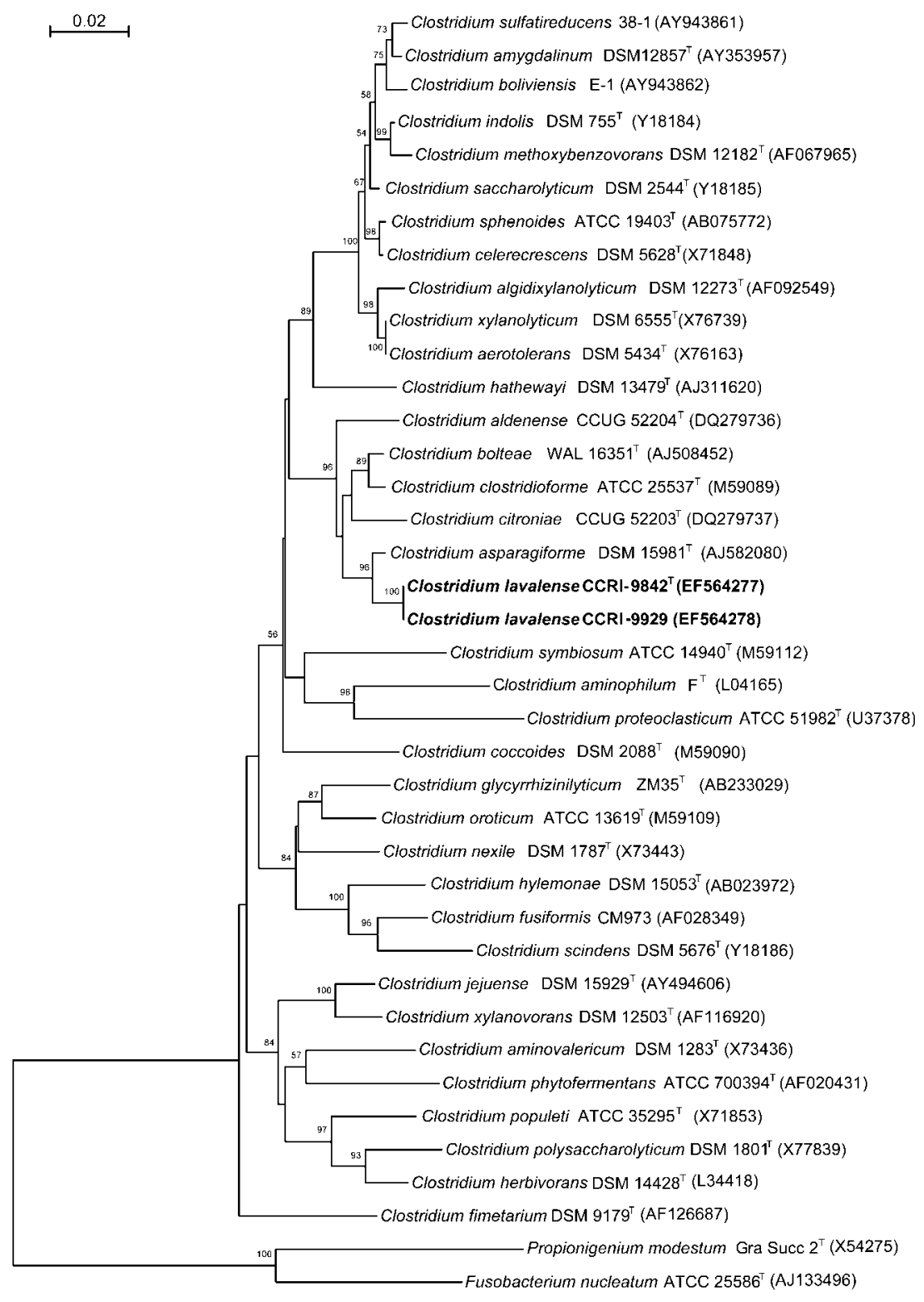

Fig. 2. Neighbour-joining phylogenetic tree, based on a comparison of partial (1118 nt) 16S rRNA gene sequences, showing the relationships of strains CCRI- $9842^{\top}$ and CCRI-9929 and related taxa within cluster XIVa of the genus Clostridium. F. nucleatum ATCC $25586^{\top}$ and $P$. modestum Gra Succ $2^{\top}$ (cluster XIX of Clostridium) were used as the outgroup. Bootstrap percentages (based on 1000 replications) are shown at branching points. GenBank accession numbers for each 16S rRNA gene sequence are given in parentheses. Bar, 0.02 substitutions per site. and ethanol were the major end products for Clostridium asparagiforme DSM $15981^{\mathrm{T}}$. Long-chain cellular fatty acid profiles showed that strains CCRI-9842 ${ }^{\mathrm{T}}$ and CCRI-9929 differed from Clostridium asparagiforme DSM $15981^{\mathrm{T}}$ in several respects (Table 2). Moreover, the branching pattern in the tree based on 16S rRNA gene sequences clearly shows that the novel bacterial isolates represent a separate species within cluster XIVa of the genus Clostridium. Despite the close relationships demonstrated to exist between the novel isolates and Clostridium asparagiforme, the data from the polyphasic taxonomic analysis presented here strongly support the classification of strains CCRI-9842 ${ }^{\mathrm{T}}$ and CCRI-9929 within a novel species of the genus Clostridium, for which the name Clostridium lavalense sp. nov. is proposed.

\section{Description of Clostridium lavalense sp. nov.}

Clostridium lavalense (la.va.len'se. N.L. neut. adj. lavalense pertaining to the institution, Université Laval, Québec, Canada).

Cells are strictly anaerobic, Gram-positive rods (0.8$1.5 \mu \mathrm{m}$ in width and $2.5-6.0 \mu \mathrm{m}$ in length) with tapered ends. Spores are subterminal (Fig. 1). Growth occurs under anaerobic conditions at $35-37{ }^{\circ} \mathrm{C}$, but no growth occurs following subculture under a $5 \% \mathrm{O}_{2}$ atmosphere. After $48 \mathrm{~h}$ incubation under anaerobic conditions, colonies are approximately $2 \mathrm{~mm}$ in diameter and greyish white in colour. Colony centres are slightly raised and the edges are rough. Zones of haemolysis are absent. The type strain, CCRI-9842 ${ }^{\mathrm{T}}$, is strongly adherent to agar media. Acetic 
Table 2. Cellular fatty acid content (\% of total) for strain CCRI-9842 ${ }^{\top}$, Clostridium asparagiforme, Clostridium bolteae and Clostridium clostridioforme

Strains: 1, CCRI-9842 ${ }^{\mathrm{T}}$; 2, C. asparagiforme DSM $15981^{\mathrm{T}}$; 3, C. bolteae DSM $15670^{\mathrm{T}}$; 4, C. clostridioforme DSM $933^{\mathrm{T}}$. Data for taxa $2-4$ are from Mohan et al. (2006). NA, Data not available.

\begin{tabular}{|lcccc|}
\hline Fatty acid & $\mathbf{1}$ & $\mathbf{2}$ & $\mathbf{3}$ & $\mathbf{4}$ \\
\hline $\mathrm{C}_{16: 0}$ & 27.96 & 14.84 & 12.6 & 25.16 \\
$\mathrm{C}_{18: 1}$ cis9 & 10.32 & 5.77 & 6.1 & 4.41 \\
$\mathrm{C}_{18: 1}$ cis11 DMA & 8.80 & $\mathrm{NA}$ & $\mathrm{NA}$ & $\mathrm{NA}$ \\
$\mathrm{C}_{14: 0}$ & 8.07 & 5.84 & 11.67 & 9.42 \\
$\mathrm{C}_{16: 1}$ cis 9 & 7.59 & 3.04 & 16.03 & 7.5 \\
$\mathrm{C}_{16: 0}$ DMA & 5.80 & 8.14 & 1.38 & 6.08 \\
$\mathrm{C}_{16: 1}$ cis9 DMA & 5.42 & 13.76 & 12.6 & 7.83 \\
$\mathrm{C}_{18: 0}$ & 2.94 & 0.43 & $\mathrm{NA}$ & $\mathrm{NA}$ \\
$\mathrm{C}_{18: 1}$ cis9 DMA & 1.29 & 5.42 & 6.07 & 4.2 \\
$\mathrm{C}_{16: 1}$ cis7 & 1.14 & $\mathrm{NA}$ & $\mathrm{NA}$ & $\mathrm{NA}$ \\
$\mathrm{C}_{16: 0}$ ALDE & 1.09 & $\mathrm{NA}$ & $\mathrm{NA}$ & $\mathrm{NA}$ \\
$\mathrm{C}_{12: 0}$ & 0.63 & 0.33 & 0.64 & 0.43 \\
$\mathrm{C}_{18: 0}$ 12-OH & 0.55 & $\mathrm{NA}$ & $\mathrm{NA}$ & $\mathrm{NA}$ \\
$\mathrm{C}_{14: 0}$ DMA & 0.49 & 1.29 & 0.67 & 2.2 \\
$\mathrm{C}_{18: 0}$ DMA & 0.47 & 0.54 & 0.26 & 0.9 \\
$\mathrm{C}_{16: 1}$ cis 11 & 0.29 & $\mathrm{NA}$ & $\mathrm{NA}$ & $\mathrm{NA}$ \\
$\mathrm{C}_{14: 1}$ cis7 DMA & 0.23 & 0.73 & 0.71 & 0.49 \\
$\mathrm{C}_{10: 0}$ & 0.21 & $\mathrm{NA}$ & $\mathrm{NA}$ & $\mathrm{NA}$ \\
$\mathrm{C}_{18: 0}$ ALDE & 0.18 & 0.41 & 1.39 & 0.47 \\
$\mathrm{C}_{20: 1}$ cis 11 & 0.17 & $\mathrm{NA}$ & $\mathrm{NA}$ & $\mathrm{NA}$ \\
$\mathrm{C}_{11: 0}$ DMA & 0.13 & 0.33 & $\mathrm{NA}$ & 0.22 \\
\hline
\end{tabular}

acid is the major end product of fermentation. The stoichiometry of the fermentation products formed from glucose for the type strain is as follows: acetic acid, $22.1 \mathrm{mEq} \mathrm{l}^{-1}$; lactic acid, $1.1 \mathrm{mEq} \mathrm{l}^{-1}$; and succinic acid, $0.2 \mathrm{mEq} \mathrm{l}^{-1}$. No other short-chain metabolic products are detected. Acid is produced from D-glucose, D-galactose, D-fructose, D-lactose, maltose, D-mannose, trehalose, sucrose and D-salicin. Acid is not produced from adonitol, amygdalin, glycerol, glycogen, inositol, erythritol, inulin, D-mannitol, $\alpha$-melezitose, L-rhamnose or starch. Utilization of D-arabinose, cellobiose, D-ribose, $\alpha$-melibiose, $\alpha$-raffinose, $\mathrm{D}$-sorbitol and L-xylose is variable (Table 1). Aesculin, gelatin and urea are not hydrolysed. Negative for lecithinase and lipase. Indole is produced. The predominant cellular fatty acids detected are $\mathrm{C}_{16: 0}, \mathrm{C}_{18: 1}$ cis $9, \mathrm{C}_{18: 1}$ cis 11 DMA and $\mathrm{C}_{14: 0}$. Resistant to vancomycin (MIC>256 $\mu \mathrm{g} \mathrm{ml}^{-1}$ ) owing to the presence of the glycopeptide-resistance gene $v a n B$.

The type strain, CCRI- $9842^{\mathrm{T}} \quad\left(=\mathrm{CCUG} 54291^{\mathrm{T}}=\mathrm{JCM}\right.$ $14986^{\mathrm{T}}=$ NML $\left.03-\mathrm{A}-015^{\mathrm{T}}\right)$, was isolated from human faecal material. The extent of the habitat is not known, but is probably the mammalian gastrointestinal tract.

\section{Acknowledgements}

We thank Emma Ongsansoy, Dominique K. Boudreau and Sandra Isabel for technical assistance. We are grateful to Professor Hans G. Trüper for his advice on the species epithet. We also thank Dr Pierre
Lebel (Montreal General Hospital, Canada) for providing the faecal specimens. This study was supported by grant PA- 15586 from the Canadian Institutes of Health Research and by grant 2201-181 from Valorisation-Recherche Québec. M.-C.D. is a research fellow from Bayer Healthcare/Canadian Institutes of Health Research/Association of Medical Microbiology and Infectious Disease Canada/Canadian Foundation for Infectious Diseases.

\section{References}

Backhed, F., Ley, R. E., Sonnenburg, J. L., Peterson, D. A. \& Gordon, J. I. (2005). Host-bacterial mutualism in the human intestine. Science 307, 1915-1920.

Ballard, S. A., Pertile, K. K., Lim, M., Johnson, P. D. \& Grayson, M. L. (2005). Molecular characterization of vanB elements in naturally occurring gut anaerobes. Antimicrob Agents Chemother 49, 1688-1694.

Bernard, K. A., Shuttleworth, L., Munro, C., Forbes-Faulkner, J. C., Pitt, D., Norton, J. H. \& Thomas, A. D. (2002). Propionibacterium australiense sp. nov. derived from granulomatous bovine lesions. Anaerobe 8, 41-47.

Collins, M. D., Lawson, P. A., Willems, A., Cordoba, J. J., FernandezGarayzabal, J., Garcia, P., Cai, J., Hippe, H. \& Farrow, J. A. (1994). The phylogeny of the genus Clostridium: proposal of five new genera and eleven new species combinations. Int J Syst Bacteriol 44, 812-826.

Domingo, M. C., Huletsky, A., Bernal, A., Giroux, R., Boudreau, D. K., Picard, F. J. \& Bergeron, M. G. (2005). Characterization of a Tn5382-like transposon containing the vanB2 gene cluster in a Clostridium strain isolated from human faeces. J Antimicrob Chemother 55, 466-474.

Eckburg, P. B., Bik, E. M., Bernstein, C. N., Purdom, E., Dethlefsen, L., Sargent, M., Gill, S. R., Nelson, K. E. \& Relman, D. A. (2005). Diversity of the human intestinal microbial flora. Science 308, 1635-1638.

Fitch, W. M. (1971). Toward defining the course of evolution: minimum change for a specific tree topology. Syst Zool 20, 406-416.

Holdeman, L. V., Cato, E. P. \& Moore, W. E. C. (1977). In Anaerobe Laboratory Manual, 4th edn. Blacksburg, VA: Virginia Polytechnic Institute and State University.

Hooper, L. V., Midtvedt, T. \& Gordon, J. I. (2002). How host-microbial interactions shape the nutrient environment of the mammalian intestine. Annu Rev Nutr 22, 283-307.

Jousimies-Somer, H. R., Summanen, P., Citron, D. M., Baron, E. J., Wexler, H. M. \& Finegold, S. M. (2002). In Wadsworth Anaerobic Bacteriology Manual, 6th edn. Belmont, CA: Star Publishing.

Kimura, M. (1980). A simple method for estimating evolutionary rates of base substitutions through comparative studies of nucleotide sequences. J Mol Evol 16, 111-120.

Mohan, R., Namsolleck, P., Lawson, P. A., Osterhoff, M., Collins, M. D., Alpert, C. A. \& Blaut, M. (2006). Clostridium asparagiforme sp. nov., isolated from a human faecal sample. Syst Appl Microbiol 29, 292-299.

NCCLS (2004). Methods for Antimicrobial Susceptibility Testing of Anaerobic Bacteria, 6th edn. Approved Standard M11-A6; 24. Wayne, PA: National Committee for Clinical Laboratory Standards.

Paradis, S., Boissinot, M., Paquette, N., Bélanger, S. D., Martel, E. A., Boudreau, D. K., Picard, F. J., Ouellette, M., Roy, P. H. \& other authors (2005). Phylogeny of the Enterobacteriaceae based on genes encoding elongation factor Tu and F-ATPase $\beta$-subunit. Int J Syst Evol Microbiol 55, 2013-2025.

Saitou, N. \& Nei, M. (1987). The neighbor-joining method: a new method for reconstructing phylogenetic trees. Mol Biol Evol 4, 406-425.

Song, Y., Liu, C., Molitoris, D. R., Tomzynski, T. J., Lawson, P. A., Collins, M. D. \& Finegold, S. M. (2003). Clostridium bolteae sp. nov., isolated from human sources. Syst Appl Microbiol 26, 84-89. 
Stackebrandt, E. \& Ebers, J. (2006). Taxonomic parameters revisited: tarnished gold standards. Microbiol Today 33, 152-155.

Stackebrandt, E. \& Goebel, B. M. (1994). Taxonomic note: a place for DNA-DNA reassociation and 16S rRNA sequence analysis in the present species definition in bacteriology. Int $J$ Syst Bacteriol 44, 846-849.

Stinear, T. P., Olden, D. C., Johnson, P. D., Davies, J. K. \& Grayson, M. L. (2001). Enterococcal vanB resistance locus in anaerobic bacteria in human faeces. Lancet 357, 855-856.
Suau, A., Bonnet, R., Sutren, M., Godon, J. J., Gibson, G. R., Collins, M. D. \& Dore, J. (1999). Direct analysis of genes encoding $16 S$ rRNA from complex communities reveals many novel molecular species within the human gut. Appl Environ Microbiol 65, 4799-4807.

Tamura, K., Dudley, J., Nei, M. \& Kumar, S. (2007). MEGA4: molecular evolutionary genetics analysis (MEGA) software version 4.0. Mol Biol Evol 24, 1596-1599.

Zoetendal, E. G., Vaughan, E. E. \& de Vos, W. M. (2006). A microbial world within us. Mol Microbiol 59, 1639-1650. 